DOI: $10.24234 /$ wisdom.v18i2.467

Oleh SOKOLOVSKYI,

Andrii KOBETIAK,

Maksym MELNYCHUK,

Oksana CHAPLINSKA

\title{
RECONSTRUCTION OF THE RELIGIOUS PARADIGM IN THE MODERN GLOBALIZED WORLD
}

\begin{abstract}
The article analyzes the process of rethinking the inherited content of human experience, established views on philosophy and religion as ideological phenomena, which are inherent in creating and transmitting the integrity of the picture of the world. Such integrity is accomplished under the conditions of preservation of each work and the pursuit of philosophical thought. It is established that the secularization and eclecticism of religious consciousness against the background of globalization processes determine the transformation of the modern religious paradigm. On the one hand, this is expressed in the need for religion to acquire adaptability to crisis phenomena and in need for special flexibility in conditions of instability and adequate perception of external variability of socio-cultural, natural and technical systems. On the other hand, in its renewed religion, it seeks to appeal to stable guidelines, ideals, and the strengthening of the influence of fundamentalism due to the belief in the need for certain traditional religious and cultural foundations. These efforts aim to preserve cultural and religious identity and facilitate survival in a world that is not structured by single expediency, ambiguous, spiritually and socially nonlinear.
\end{abstract}

Keywords: religion, paradigm, worldview, society, globalization, secularization, orthodoxy.

\section{Introduction}

The need to define a clear, coherent strategy of political, economic, spiritual and cultural development and guidelines of world powers has necessitated a thorough lemmatization of their geopolitical self-identification in the context of global problems of today. The actualization of geopolitical demands is caused both by the transition of world civilization to the formation of a planetary social organism and by the rapid progress of society. At the same time, society is responsible not only for preserving and restoring the life of its community and implementing the principles of sustainable development of social organization of life but also for cultivating spiritual dimensions, taking into account the clericalization of modern social life and politicization of religion. Note that the definition of the concept of the spiritual belongs to religion, which in philosophical and philosophical teachings is traditionally represented by an integral component of national policy. Hence we can state the need to explain the level of interaction and interaction of foreign and domestic policy of states, their economic and political systems with spiritual and religious systems.

Globalization processes in the modern world have shown the existence of a moral crisis caused by the loss of Christian values. Cultural identity in the modern era must be based on the free choice of a person who does not violate the freedom of choice of another. A person can choose a religion to his liking, which contradicts the algorithm of traditional religion. This is not the first attack of globalization on traditional cul- 
tures and spiritual life of humanity, but the current globalization is much larger than the previous ones - it actively interferes in the spiritual world, and not as secondary and derivative, but as independent and self-sufficient (Fylypovych, 2010, p. 3).

This circumstance has led not only the clergy to rethink the limits of interpretation of Christian truths in the information field but also to involve scholars in this process in order to preserve the spiritual culture of the individual. The Church and society are convinced that the level of technological development of humankind can find mechanisms to solve most global problems, except for the socio-ideological algorithm of intercultural interaction, which constantly hides the landmine (Saukh, 2013, p. 23). Religion endows human communities with powerful symbolism and builds boundaries between them, which are inaccessible to interpenetration. Therefore, accepting globalization as a factor of historical development, it is desirable to move away from the prevailing notion of globalization as a process that brings merely destruction to traditional cultures (Fylypovych, 2010, p. 4). However, in these circumstances, one cannot fail to notice that the main trend of the modern religious process is its fundamentalisation as a reaction to modernism, which has led to the liberalization of beliefs subject to rethinking in order to adapt churches to new social and spiritual conditions.

\section{Results and Discussion}

Globalization development always leads to unification and integration. In the spiritual and religious sense, this leads to a smoothing of the cultural and national characteristics of religions. The consequences of this process are unambiguous. On the one hand, the destruction of traditional spiritual foundations is taking place; on the other hand, it is a process that cannot be avoided on the way to the formation of a peculiar system of values of a certain people (Fylypovych, 2010, p. 5). Thus, the evolutionary development of re- ligion on a global scale leads not only to the loss of national identity but also to the accumulation of the common that is characteristic of each tradition. Therefore, globalization must be seen not only as a threat but also as an opportunity for various transformations. Only the right priorities will allow you to reap the full benefits of globalization. Prolonged and systematic neglect of opportunities will lead to the inevitable closure of interreligious contacts.

Different religions in their activities and functionality direct a person to the full disclosure of his spiritual potential. In performing this function, they are guided by the realities of the world. One of the main factors in the modernization of theology is the human demand for the transcendent. In different socio-cultural, political, economic conditions, these requests become widespread and differ in their content. However, unlike unorthodox philosophical teachings, modern religious paradigms seek to preserve their innovations within the religious worldview. This is achieved both by ideological and dogmatic means and by the cult and institutional means.

The formation of the main principles of modern geopolitical thought belongs to the founder of political geography F. Ratzel who formulated a geographical-spatial approach in elucidating the nature and specificity of political events. The German scholar gave a vital place to the role of religion in these events because only language and religion should be preferred to other manifestations, as nobler and those that bring them closer to the mind (Ratzel, 2003, p. 80). In his biogeographical concept, he argued that the state of the state as part of humanity directly depends on the interaction of space and geographical location. By space, F. Ratzel understood both territorial borders and living space, the size of which testified to the power and prosperity of the state, and the increase of the territorial perimeter was provided by active trade and missionary work.

The ideas of the German scientist about the state as a complex structured quasi-organism that functions in space and based on biological and 
geographical influences seek to expand, continued R. Chellen. The Swedish scientist became not only the founder of geopolitics as a concept but also an analyst of the peculiarities of management in order to identify effective methods and principles of creating a strong state and ranked the dependence of its progress on territory population, economy, social order and power. Given the multifaceted spectrum of determinations and contextualizations of geopolitics today, it is interpreted as a doctrine of the state with a dominant appeal to its territorial component in the system territory - population - power.

Over the past century, the definition of geopolitics, acquiring new aspects, has changed to the current in sociology, the political direction of the state. Thus a classical mode in its interpretation was formed. In particular, the combination of ideas of cultural and historical communities (M. Danilevsky), models of archetypes (K. Jung) and hypotheses of civilizations (A. Toynbee). At the same time, the concepts of S. Huntington's "clash of civilizations", E. Toffler's third wave, and others appeared. At the end of the twentieth century, two geo-projections of society as geoeconomics and geo-culture were formed, based on modern globalization demands. In general, the evolution of geopolitics distinguishes different stages, which are characterized by the formation of geographical determinism with its idea of the dependence of the origin and development of religion on the geographical environment, established traditions, the political and economic structure of a state due to natural factors.

Given those modern imperatives of geopolitical theory involve rethinking key categories of traditional geopolitics in order to analyze the sequence in the process of distancing from the linear-planar worldview, we single out the natural factor, spatial parameters and interaction of politics and religion as leading factors. Under natural factors, the complex of climatic, landscape, bioresource natural conditions as an antecedent of development of a religious phenomenon is considered. During the historical evolution of hu- manity, the significance of geographical and climatic conditions in promoting the emergence and further development of society is gradually being lost. However, the issue of interaction of society as a form of organization of human life as a virtually infinite set of objective processes and phenomena and a biological substrate of man, his body with all its inherent functionality, continues to be discussed. At the same time, attempts to comprehend the reverse influences of religion as a spiritual activity of man and the world of nature as an objective prerequisite for socio-cultural human existence and its semantic component are becoming intense.

The plurality of Christianity's views on nature and its interaction with society is determined by both identical and different positions due to the peculiarities of the semantic philosophical and religious worldviews inherent in the corresponding type of society. Early Christian anthropology and Christology is based on the concept of creating man in the image and likeness of God, produces the initiative of spiritual and practical activities, active and creative attitude to themselves and nature. Instead, in the Renaissance, the dominant position was the identification of God through creation, which meant nature. The paradigm shift took place in Protestant theology, which, thanks to the doctrine of personal faith, deprived nature of the function of reflecting God's grace. Protestantism was based on the assertion that nature is an order established by God and man, separating himself from nature, loses its semantic dependence on it (Kalvin, 1997, p. 52).

The dominance of worldview paradigms of empiricism and rationalism played an essential role in shaping the utilitarian approach in the unconditional intervention and exploitation of natural resources with devastating consequences. Philosophical paradigms and the Christian worldview of man's remoteness from nature have led to the current ecological crisis. Note that this is a crisis of value and moral orientations of nature as a person with his selfish ideas of conquest, mastery, transformation, and society, in 
general, with its political, economic, scientific institutions and systems.

The multifaceted interpretation of geopolitics has led to the transformation of the content of its subject of study from the geopolitics of space to human geopolitics. Given that the basis of human spiritual existence is religion, and the basis of the religious dimension is the religious choice and religious affiliation, of particular importance, is the three-level geo-projection of the explication of society, according to which the problem field of scientific views is consistent. In this context, A. Toynbee rightly remarked on the relationship between civilization and religion, in a certain type of which the most noticeable focus is the production of the spiritual elite of the relevant meanings and values as the basis of a certain type of civilization. That is why to overcome the crisis of civilization, and the English philosopher recommended returning religion to a decent place in society (Toynbee, 2006, p. 550).

The level of democratization of society directly corrects its political, economic, socio-cultural life, affects its spiritual state and human spirituality, the basis of which is religious affiliation. The higher the level of democratization of society, the more constructive the state-church relations, and the more tolerant the representatives of power and religion. Given the finding of mechanisms for the state to maintain stability in the religious environment and avoid politicized involvement and regionalization of policy in state-church relations, analysing the relationship between ideology and religion is relevant.

Scientific research on the relationship between ideology and religion aims to reveal the essence of religious ideology as a determinant of society, determining the influence of ideology as one of the elements of social consciousness on religion. Ideology and religion focus on several humanities, which in their context reflect their essence, historical processes and functionality in society. Analyzing the peculiarities of the formation, transformation and essence of ideology, researchers compare the emergence of religious ideology with the emergence of an objective need for it in the formation of a class antagonistic society, when religion as a social phenomenon projected ambivalent intentions. First, religion continued to be a belief in the transcendent, in the Higher Beginning, to which man is involved by realising his godlikeness. Secondly, in religion, a system of ideas was introduced, focused on the preferences of the operating system. The dominance of religious ideology in society has led to the obligatory acquisition of religious colour by socio-political movements and to the inclusion of churches, religious organizations in political structures and especially in the state (Klymov, 2009, p. 169).

In the relationship between ideology and religion, scientists characterize such oppositional concepts as superficiality - depth, flow - eternity. However, a particularly pronounced polarization between them was observed in relation to the human at the level of definition of these concepts, and given the lack of a single definition and understanding of religion as a phenomenon and the presence of different approaches to interpreting religion as a phenomenon, religion is interpreted as (Men, 2002, pp. 74-75).

Unlike religion, ideology is primarily aimed at the masses as a system of ideas to protect the interests of social groups, society, while the individual, his freedom, needs are considered in the context of usefulness to society. On the other hand, religion appeals to the personal, impossible without its own spiritual experience, the meaning of which is not in the formal implementation of religious precepts and precepts, but in the restoration of man's divine image of his personality because he feels his existence as a problem (Fromm, 1988, pp. 444-445). Thus, ideology and religion form a kind of symbiosis, the bifurcation point of which is a functional approach that determines the effectiveness, influence and significance of religion for man and community. In establishing this approach, attention is focused on religion as a collective phenomenon that integrates people into a certain moral community on 
the basis of a collective system of beliefs and practices (Dyurkgeym, 1994, pp. 35-69).

In this context, Hegel (2007) rightly noted that any religious movement that gives people a sense of confidence and determination will always find its followers (pp. 282-283). The German philosopher noted that there have always been attempts to establish only the external, conditioned necessity of religion, where it acts as a means, something intentional, accidental, in itself does not matter, something that can be either rejected or used for a specific purpose. However, it is in religion, as Hegel points out, that everything secret in man receives its justification: decency, conscience, a sense of duty, and so on. Therefore, the state must rely on religion because it is in it that the reliability of people's way of thinking and their readiness to fulfil their duty to the state become absolute. In turn, contempt for God destroys the consciousness of their rights and responsibilities, weakens the bonds of family and state and leads them to death (Hegel, 2007, pp. 140-141). This thesis characterizes Hegel's external necessity of religion. However, he notes that the spirit becomes completely free to choose goals largely due to religion. In this way, the spirit can realize the objective goals that are most valuable to it while sacrificing particular goals.

Modern geopolitics is associated with such social actors as the state, economic and political unions and individual leaders, whose tasks are targeted activities focused on the public interest. Note that on the basis of a comparative analysis S. Huntington, determining the place of the Reformation movement in political processes, found an analogy between it and the political manifestations of the Islamic revival. The content of this manifestation lies in the same root causes of these phenomena, namely the reaction to the stagnation and corruption of the main institutions of the society of that time and the real tasks of the leaders of these movements to return to religious purity of faith and exactingness. The proclamation of active activity, observance of order and discipline, and the conduct of initiative mis- sionary work aimed at attracting middle-class representatives to their denominations (Hantington, 2003, p. 165).

The ability of various denominations to some extent is determined by economic, political, cultural and other social modes. In this perspective, the comprehension of the manifestations of another representative, along with the natural factor of classical geopolitics, namely the spatial and territorial attributes of society. They are considered in the coordinates of geographical location, neighbourhood, living space, and in the perspective of coverage of international relations, demography and other geopolitical concepts, which to some extent determine the confessional expressions of orthodoxy as an integral part of history and cultural and religious life.

Tendencies towards multilevel integration, the priority of which was represented by geographical neighbourhood, have been observed during many historical stages. The history of civilizational development can be seen as a change in integration processes, involving growth, development, unification, or conquest, enslavement, assimilation and disintegration as a stage of decline of a particular culture. The main feature of this stage is the constitution of a decrease in interest in spiritual values or liberation, the emergence of new nations, depending on geopolitical preferences for a particular state or nation. Elements of national cultural integrity are, first of all, cultural and religious phenomena and the limits of their interactions with the cultural policy of the state. According to P. Kozlovski, the modern state cannot determine the practice of religion in its policy. It can encourage philosophy as a culture of self-giving and self-knowledge (Kozlovski, 1997, p. 76).

Territorial stratification of cultures of a certain ethnic group determines the specifics of religion as a mandatory segment of cultural and anthropological life. Based on the statistics of religious choice of the population of European countries with their field of confessional composition and capitalist development as an economic system, 
M. Weber noted the undeniable quantitative dominance of Protestants among capital owners, financiers, entrepreneurs and workers. The German philosopher defined this situation as one in which religious affiliation was not the cause but, to some extent, the consequence of economic phenomena (Weber, 1994, p. 38).

Note that the Reformation movement in Germany began with the declaration of freedom both as a ministry. The essence of this paradox is freedom, consonant with its main poles, such as freedom and the need to exist. Man's doom to freedom and the assertion of the most worthy freedom through self-restraint recognises God as the cause of all phenomena and events, human behaviour and the proclamation of service to Christ. We emphasize that the theology of early Protestant currents in a laconic form was based on two general postulates:

1. The source of faith - the Holy Scriptures (the Holy Father's theological heritage was rejected or refuted in the process of discussion) (Spits, 2005, p. 57);

2. The salvation of man depends only on faith (the importance of rituals and good deeds is denied) (Prilutskiy, 2004, p. 66).

In this regard, special attention should be paid to the reformist theology of one of the leaders of the Protestant movement in France, J. Kalvin. Calvinism is genetically related to the Swiss branch of Protestantism, the founder of which was W. Zwingli, while J. Kalvin is considered the successor and finalist of his work (Sokolovskyi, 2018, p. 321).

Despite the well-established view that J. Kalvin (1997) depicts human nature damaged by the Fall, he noted that human nature, although it has lost its integrity and is deeply damaged, has many gifts of God (p. 270). Among the natural gifts of J. Kalvin (1997) refers to the knowledge that a person can develop in science, crafts and art (pp. 269-270). Given that the abilities in these areas may show and not virtuous people, it becomes clear the judgments of the reformer on this division. Man's misuse of his talents is a consequence of his loss of supernatural abilities. However, the moral aspect for J. Kalvin is not dominant in the fall of man. After the fall, the gift left to man, the mind, along with human nature, was also damaged (Kalvin, 1997, p. 266). The consequence of sinful damage to the mind was a distorted perception of being (Kalvin, 1997, p. 34) and a person's tendency to make mistakes (Kalvin, 1997, pp. 57-58). Only in earthly affairs, according to J. Kalvin, is the full capacity of the mind manifested. At the same time, states the theologian, the human mind is not able to know the divine side of the essence. Human intervention in this area leads to idolatry and superstition. The only way to comprehend the seed of divine order is the Son of God, Jesus Christ.

Followers of Calvinism later condemned the proclamation of the French Revolution's motto for human sovereignty as a direct source of power and freedom. It has become a traditional idea for Christians that if a person has rights and freedoms, they are God's gifts. This explains the peculiar prudence of the reformers in violating the interpretation of the subject of rights and freedoms proposed by the figures of the bourgeois revolutions as defined and established by the man himself on the basis of his own "I" and certain philosophical or religious principles. The theologian, A. Ehmond, spoke in this regard, considering that a distinction should be made between declarations of American origin, where rights are still based on God the Creator, and declarations of French origin, where such a justification is clearly lacking. It is the latter who are under devastating criticism from Calvinists. The religious anthropology of Calvinism clearly rejects human rights as an idea, as an ideology (Ehmond, 2000, p. 279).

Mutual cooperation of the state and the church is a necessary condition for a full-fledged spiritual and religious human existence. The church's most important task, Reformist theology in the relationship between church and state, adhered to the position of assistance and respect 
by the faithful of power. The teaching declared that the church and the state arose and were built on the will of God as a common foundation transmitted through the Holy Scriptures. In this regard, E. Fromm (1988) noted that a significant impetus to the development of political and internal, spiritual freedom of the individual and society as a whole was expressed by Protestants concept of faith and salvation, based primarily on personal merit (p. 90). Thus, the geopolitical situation of the New Age produced a comprehension of the meaning of human existence through the prism of the worldview formed by the ideologues of the Reformation movement. They declared adequate to the new economic and sociocultural realities views on work and professional activity.

The German philosopher M. Weber studied the influence of religion on the formation of economic ethics and the regulation of the economic definition of the bearers of the Protestant faith. Through comparative analysis, he proved that the most effective Protestant denomination, whose religious principles contributed to the emergence of the capitalist spirit in France, the Netherlands, Germany, and some other Western European countries, was the Reformation. Attitude to the spirit of capitalism, according to M. Weber, facilitated adaptation to the rational requirements of the economic system under capitalism, non-involvement in the form of indifference or lack of proper competence in adapting economic behaviour and a certain way of life led to a kind of obstacle to rational capitalism. Thus, in the context of the new paradigm, a social ethic was formed, which, based on the principles of systematic lifestyle and professional ethics, defined the spirit of capitalism.

Under current circumstances, the spirit of capitalism is relevant to the mentality when people are simultaneously enriched by purposeful professional activity and consciously limited in consumption costs, giving certain ascetic features to their way of life. The importance of Protestantism for the development of the capitalist spirit was that Protestantism was the first religion to condemn poverty and arouse interest in material goods. Calvinism, in its own interpretations of the Gospel commandments, insisted on selfless, tireless work and maximum labour achievements as a means of affirming the greatness of God.

\section{Conclusion}

Thus, in the modern globalized world, with its dynamism, deepening interethnic, interstate, interreligious contradictions, the need to resolve these contradictions has become especially acute. It is important to consider geopolitics as a worldview and philosophical concept, political principle and practice, taking into account the latest trends in the metamorphosis of international relations from a geopolitical paradigm to a geo-economy. Recourse to fundamental principles is also becoming a leading trend in modern religious life. The desire not only to find and reconstruct the authentic basis of faith but also to preserve the invariance of primary dogma and orthodoxy as an undoubted basis of doctrine, justified by the need for confessionalization or common semantic integrity, identity in terms of rhodium diversity. On the way to the implementation of these processes are favourable, and therefore relevant are religious constants. Through the prism of the unfolding of civilizational space, the study provides new readings of religious paradigms within global transformations and national cultures in their unique expression.

\section{References}

Dyurkgeym, E. (1994). Elementarnye formy religioznoi zhizni. Totemicheskaya sistema v Avstralii. Sotsiologiya religii. Klassicheskie podkhody. Khrestomatiya (Elementary forms of religious life. Totemic system in Australia. Sociology of religion. Classic approaches. Chrestomathy, in Russian). Moscow: INION.

Ehmond, A. (2000). Kalvinistska dumka i prava 
liudyny (Calvinist Thought and Human Rights, in Ukrainian). Religijna soboda i prava lyudy'ny': bogoslovs'ki aspekty' (Religious Freedom and Human Rights: Theological Aspects, in Ukrainian), 1, 193-304.

Fromm, E. (1988). Puti iz bol'nogo obschestva (Paths from a sick society, in Russian). Problema cheloveka v zapadnoi filosofii (The Human Problem in Western Philosophy, in Russian). Moscow: Progress.

Fylypovych, L. (2010). Hlobalizatsiia relihiinoho thyttia ta perspektyvy konfesiinoho rozvytku v Ukraini (Globalization of religious life and prospects of confessionnal development in Ukraine, in Ukrainian). Religiya ta socium (Religion and Society, in Ukrainian), 2, 3-6.

Hantington, S. (2003). Stolknovenie tsivilizatsii (Clash of civilizations, in Russian). Moscow: OOO "Izdatel'stvo AST".

Hegel, G. (2007). Filosofiya religii (Philosophy of religion, in Russian). Moscow: ROSSPEN, 1.

Kalvin, J. (1997). Nastavlenie v khristianskoi vere (Instruction in the Christian faith, in Russian). Moscow: Izdatelstvo RGGU.

Klymov, V. (2009). Svoboda sovisti, tserkva, relihiinist v ukrainskomu suspilstvi periodu nezalezhnosti: Vybrani statti (Freedom of conscience, church, religiosity in the Ukrainian society of the period of independence: Selected articles, in Ukrainian). Kyiv: Vid-nia relihiieznavstva In-tu filos. im. H. S. Skovorody NAN Ukrainy.

Kozlovski, P. (1997). Kul'tura postmoderna: Obschestvenno-kul'turnye posledstviya tekhnicheskogo razvitiya (Postmodern culture: Social and cultural consequences of technological development, in Russian). Moscow: Respublika.
Men, A. (2002). Bibliologicheskiy slovar (Bibliological dictionary, in Russian). Moscow: Fond imeni Aleksandra Menya.

Prilutskiy, A. (2004). Istoriko-filosofskie predposylki formirovaniya ekzegeticheskoi paradigmy Martina Lyutera (Historical and philosophical prerequisites for the formation of the exegetical paradigm of Martin Luther, in Russian). Bogoslovskie razmyshleniya. Evroziatskij zhurnal bogosloviya (Theological Reflections. Eurosiatic Journal of Theology, in Russian), 3, 65-85.

Ratzel, F. (2003). Narodovedenie (antropogeografiya). Klassika geopolitiki, XIX vek (Ethnology (Anthropogeography). Classics of geopolitics, XIX century, in Russian). Moscow: OOO “Izdatel'stvo AST".

Saukh, P. (2013). Suchasni vyklyky hlobalizovanoi epokhy: suspilstvo i tserkva v poshukakh vidpovidei (Modern challenges of the globalized era: Society and the church in search of answers, in Ukrainian). Ukrayins'ke religiyeznavstvo (Ukrainian Religious Studies, in Ukrainian), 66, 19-27.

Sokolovskyi, O. (2018). Hristologiya: evolyuciya doktrini: monografiya (Christology: The evolution of doctrine: A monograph, in Ukrainian). Zhitomir: Vid-vo Yevenok O. O.

Spits, L. (2005). Istoriya Reformatsii. Vozrozhdenie i dvizhenie reformatsii. Lyuteranskoe nasledie (History of the reformation. Revival and reformation movement. Lutheran heritage, in Russian).

Toynbee, A. (2006). Postizhenie istorii (Comprehension of history, in Russian). Moscow: Ayris-press.

Weber, M. (1994). Protestantska etyka i dukh kapitalizmu (Protestant Ethics and the Spirit of Capitalism, in Ukrainian). Kyiv: Osnovy. 